\title{
Quality Analysis of Earnings Reported by Banks in Dynamic and Less Dynamic Financial Markets by Applying IAS 39 for Measuring Financial Instruments-Case Study: Mozambique and Portugal
}

\author{
Crisódio José Elias, Amarildo Pena Vasco \\ Economy and Management Department, Instituto Superior Politécnico de Gaza, Chókwè, Mozambique \\ Email: neliasbanze@gmail.com, amarildorylldo@gmail.com
}

How to cite this paper: Elias, C. J., \& Vasco, A. P. (2020). Quality Analysis of Earnings Reported by Banks in Dynamic and Less Dynamic Financial Markets by Applying IAS 39 for Measuring Financial Instruments-Case Study: Mozambique and Portugal. Open Journal of Accounting, 9, 36-49.

https://doi.org/10.4236/ojacct.2020.93004

Received: June 2, 2020

Accepted: July 28, 2020

Published: July 31,2020

Copyright (๑) 2020 by author(s) and Scientific Research Publishing Inc. This work is licensed under the Creative Commons Attribution International License (CC BY 4.0).

http://creativecommons.org/licenses/by/4.0/

\begin{abstract}
The present study aimed to analyse the quality of the earnings reported by banks inserted in dynamic and less dynamic financial markets, associated with IAS 39 as measurement standard of financial instruments, from 2013 to 2017. The study consisted of the analysis discretionary accruals of banks operating in different markets, namely Mozambican and Portuguese. Discretionary accruals were estimated based on the modified Jones (1991) model. The study results indicate that there is evidence of discretionary behaviour in the reported earnings, and is high to the dynamic markets context. On account of the previous finding, the study has drawn the differences in the use of financial instruments. It was found out that Mozambican banks use few instruments; however, the difference is meaningless. A gross part of Financial Instruments Available-for-Sale and used by Mozambican banks are made up of treasure obligations, which may partly explain the reduced discretionary behaviour compared to Portuguese banks.
\end{abstract}

\section{Keywords}

Dynamic, Markets, Discretionary, Accruals, Banks

\section{Introduction}

Over the last decades, globalization and the consequent internationalization of accounting standards have been adhered by many countries, whether developed or developing. Along this path, Mozambique has successfully implemented ma- 
jor financial sector reforms that substantially improved its development, one of which was the introduction of the International Financial Reporting Standards (IFRS), as Mozambique adopted IFRS in 2010. This was done to harmonize accounting principles and concepts, so that all entities can operate in the context of a single market.

Several studies have been carried out in order to analyse some accounting practices established by international standards and their impact on the information disclosed in the financial statements (e.g. Khan, 2010 and Butler, 2009). The results obtained give rise to international debates that partly contribute to the improvement and evolution of standards. This study joins these debates and integrates a context rarely analysed in the case of Mozambican Banking Institutions.

Financial institutions, especially banks, by their nature massively accumulate financial instruments in their assets and liabilities. The accounting treatment of these instruments has, for some time, been regulated by International Accounting Standard 39 (IAS 39), and currently replaced by International Financial Reporting Standard 9 (IFRS 9). The evolution and its revocation are a consequence of the normative evolution induced by several events including the last financial crisis.

Since the database was constituted by the period before IFRS 9 , the approach of this study is concentrated in the context of IAS 39. This standard defines different categories of financial instruments, namely: 1) Financial instruments at fair value through profit or loss; 2) Financial instruments held to maturity; 3) Loans \& receivables and 4) Financial instruments available for sale. The classification of financial instruments moves the successive measurement and the possibility of reclassification also determines how the same instrument starts to be measured.

According to Khan (2010), creative accountants can explore the opportunities that the standard presents to make choices that can lead to changes in the institution's financial situation in the most convenient way. The opportunities for these choices are likely to multiply as more diversified financial instruments are available, such as Banks located in dynamic financial markets, for example in Portugal. The opposite may eventually happen for emerging financial markets, for example in Mozambique. These differences can move the discretionary levels presented in the two contexts, so the following question emerges:

"What differences in discretion do banks have that trade in dynamic markets and those in less dynamic markets?"

Consequently, the study seeks to analyse the differences in the discretionary levels of financial institutions, in the context of emerging and dynamic markets. To this end, the following specific objectives were achieved: 1) Estimate the discretionary increases of the banks selected for the sample; 2) Compare discretionary additions to asymmetric financial market contexts; 3) Compare the use of financial instruments according to their classifications. 
As previously mentioned, normative developments stem from studies, debates and events that lead to out-dated or inadequate standards. This study joins these debates and in particular will seek to contribute to particular analyse of the African context that plays a passive role in international standardization. The succession of similar studies, will make it possible to identify specific problems associated with the implementation of international standards in Africa and afterwards, will improve the positioning of the bodies that ensure normalization as well as the regulators of financial institutions. In particular, that may be the target of financial fragility, bankruptcy and discrediting the local financial system.

The paper is presented in 4 sections, consisting of the literature review, methodology, results and discussions, and finally conclusions and future research lines.

\section{Literature Review}

This section addresses the theoretical foundations that underlie managers' decisions to manipulate reported results in the financial statements. Specifically, literature was selected that supports the possibility that the IAS 39-measurement standard of financial instruments is likely to create opportunities for accounting choices that can change earnings. In this section, contextual differences in financial markets are exposed that may partly influence differences in discretionary behavior, precisely in the case of Mozambique and Portugal.

\subsection{The Positive Accounting Theory and Earnings Manipulation}

The present study is based on Positive Accounting Theory. According to Buchweitz, Pereira, Da Cruz and Barbosa (2019), authors of this theory are Watts and Zimmerman, who inspired by the positive economy spread and introduced the present theory through Positive Accounting Theory 1986 and later by the article Positive Accounting Theory: A Ten Perspective, published in The Accounting Review in 1990. Positive Accounting Theory (PAT) aims to provide explanations and predictions for accounting practice based on accounting policies adopted by company managers (Silva, Silva, Souza, Borges, \& Araujo, 2015).

Silva (2008) states that PAT assumes that there are agreements, explicit or implicit, between stakeholders in the company, such as shareholders, managers, creditors, suppliers, customers, government and others, where each participant contributes something to the firm and in return receives a counterpart. The PAT is based on the idea that agents are guided by their personal interests always seeking to maximize their well-being.

PAT argues that there are two perspectives to explain accounting practice choices: informational perspective and contractual perspective (Watts \& Zimmerman, 1990). These authors refer that the informational perspective investigates the relationship between accounting numbers and the stock market price, while the contractual perspective seeks to explain the existence of manipulation in the Financial Statement (FS), as pointed out by Silva (2008), that the choice of 
accounting practices performed by managers are generally explained based on the Firm's Contractual Theory, as such contracts give rise to firm contractual costs.

According to Watts and Zimmerman (1990), contract costs include the following: transaction costs (e.g. costs of appraising, negotiating and writing contracts, including negotiating fees); agency costs (e.g. costs associated with fundraising); information costs (e.g. costs of keeping track of contract performance); renegotiation costs (e.g. costs to rewrite existing contracts); and bankruptcy costs (e.g. bankruptcy implementation and administration costs).

PAT presents hypotheses that guide studies to explain and predict accounting practices adopted in organizations, since the hypotheses present correlations between accounting methods to be used and decisions made by managers based on their interests (Silva et al., 2015). There are three main factors that influence accounting practices: compensation plans, degree of indebtedness and the political costs linked to company size. These authors mentioned above developed the Positive Theory Hypotheses: 1) Incentive Plan Hypothesis; 2) Hypothesis of Indebtedness; and 3) Political Cost Hypothesis.

\subsection{Earnings Manipulation Incentives}

Moreira (2013) states that company managers adopt measures to earning manipulation based on incentives that are based on the expectation of obtaining a benefit, personal or company or expectation to avoid a penalties. This author further admits that manipulation is not directly perceived from the FS, as the information of incentives that influence managers at each moment is. However, it is important for information users to be able to make sense of the evidence that the empirical analysis of financial information may provide them with, or to intuit the nature and direction of the potential misstatement included in the earnings through such manipulation.

Healy and Wahlen (1999) make up three main groups of incentives for earnings manipulation, which are: 1) Capital market-related incentives-these incentives encourage company managers to report earnings that do not detract from the expectations of investors and analysts, otherwise the share price will fall and managers will find it more difficult to be reappointed and/or affected by their salary bonus; 2) Contractual incentives - these imply the existence of contracts that impose penalties if the company does not reach certain accounting ratios, since when the companies perform poorly and they risk incurring such penalties, the incentive faced by managers leads them to manipulate the penalties upwards so as to avoid surpassing these ratios. 3) Legal incentives-the authors states that this is similar to the previous incentive, as they differ in origin, because they result from legal or regulatory precepts.

In this context, the incentives for manipulation cannot be detached from the legal and economic context in which the companies carry out their activity, and when analyzing the FS or when considering the situations of potential manipula- 
tion, it is important to bear in mind the potential incentives that may be behind the attitudes of companies (managers), even to be able to understand and interpret the empirical evidence obtained (Moreira, 2013). Based on the literature review previously exposed, the following research hypothesis is raised: $H_{1}$-There is discretionary behaviour in both Mozambican and Portuguese banks.

The discretionary behaviour can be tested by the modified Jones's Model as is shown in the next section.

\subsection{Mozambique Stock Exchange (BVM) and Financial Instruments Measurement}

BVM was created by the Mozambican government in 1997. According to the BVM, there are currently (9) listed companies. Table 1 shows the evolution of the main indicators of the Mozambican stock market over the last 3 years (2016 to 2018).

Based on the Comissão do Mercado de Valores Mobiliários (CMVM, 2018), it was possible to identify higher market liquidity (Turnover) compared to the Mozambican context, having observed for the years 2016, 2017 and 2018 a turnover of $50.5 \%, 52.4 \%$ and $44.7 \%$ respectively. This finding demonstrates BVM's inflexibility with regard to the level of securities trading, which is below $10 \%$ as shown in Table 1.

The previously presented contrast allows us to demonstrate the difference between financial market contexts. Assuming that financial markets, once developed, offer a diversified possibility of acquiring and trading different financial instruments, from simple to complex ones, then it is expected that the opportunities and behaviour of accountants vis-à-vis the accounting of financial instruments will be different.

The International Accounting Standard $39^{1}$ (IAS 39) provides that an entity shall recognize a financial asset or financial liability on the balance sheet when, and only when, the entity becomes party to the contractual provisions of the instrument. This standard also states that the measurement of financial instruments occurs in two stages: the initial and the subsequent. The initial measurement for

Table 1. BVM key indicators in the last 3 years (2016 to 2018).

\begin{tabular}{cccc}
\hline Stock Indicators (Mean) & 2016 & $\mathbf{2 0 1 7}$ & $\mathbf{2 0 1 8}$ \\
\hline Listed Companies & 4 & 6 & 7 \\
Stock Market Capitalization (Million MT) & 59124.15 & 65507.57 & 79720.75 \\
Transaction Volume (Million MT) & 1443.27 & 3194.74 & 2042.50 \\
Turnover (\%) & $2.37 \%$ & $4.75 \%$ & $2.49 \%$ \\
Market capitalization as \% of GDP & $8.62 \%$ & $8.22 \%$ & $8.15 \%$ \\
\hline
\end{tabular}

Source: Adapted from BVM Statistics: Mozambique Stock Exchange.

${ }^{1}$ Notwithstanding the changes brought by International Financial Reporting Standards 9 (IFRS 9), this article addresses the context of IAS 39, given that the financial statements considered for the present study precede the period of implementation of the recent standard (2012-2017). 
all financial instruments is made to the Faire Value (FV).

Subsequent measurement of a financial asset is directly dependent on the classification of the financial asset as it can be classified as: Financial assets by the FV through profit or loss; Held-to-maturity investments; Loans and receivables and Available-for-sale financial assets. The last instruments including derivatives may be measured at its FV upon initial recognition. Subsequent measurement of a financial liability occurs after recognition at the initial moment, and an entity shall measure all financial liabilities at amortized cost using the effective interest method (IAS 39).

According to IAS 39 we can find 4 categories of financial instruments: Financial Instruments Held for Trading (FIHT), Financial Instruments Held to Maturity (FIHM), Loans and Receivables (LR), and Financial Instruments Available for Sale (FIAS).

A financial asset or liability is classified as an FIHT if 1) it is acquired or incurred primarily for the purpose of selling or repurchasing in the short term;2) upon initial recognition, it is part of a portfolio of identified financial instruments that are jointly managed and for which there is evidence of a recent actual pattern of short-term profit making, or whether it is a derivative (except for a derivative which is a financial collateral agreement or a designated and effective hedging instrument (IAS 39).

FIHM's are non-derivative financial assets with fixed or determinable payments and fixed maturities that an entity has the positive intention and ability to hold to maturity. LR's are non-derivative financial assets with fixed or determinable payments that are not quoted in an active market. FIAS's are those non-derivative financial assets that are designated as available for sale or that is not classified as 1) loans and receivables; 2) investments held to maturity; or 3) financial assets to the FV through profit or loss (IAS 39).

IAS 39 not only classifies instruments but also offers the possibility of reclassifying financial instruments, right, with some limitations. These openings gives an opportunity for accounting choices aimed at changing reported results (Khan, 2010). The study seeks to verify whether the difference in markets associated with the difference in trading opportunities with financial instruments is based on the following prediction: $\mathrm{H}_{2}$-Mozambican banks have smaller discretion than Portuguese banks and $\mathrm{H}_{3}$-Less use of financial instruments by the FV is associated with low discretion.

Basically both hypotheses will be tested by comparison of the groups. The next section gives details.

\section{Methodology}

The study was based on a sample of 24 banks, 9 for Mozambique and 15 for Portugal, as Table 2 shows. The choice is justified because they are countries whose characterised by their asymmetric dynamism. The differences was exposed in the previous section using the common activity indicators of the Stock 
Table 2. Banks of the sample.

\begin{tabular}{ccc}
\hline No. & Mozambican's Banks & Portuguese's Banks \\
\hline 1 & BIM & BCP \\
2 & BCI & B. Carregosa \\
3 & Standard Bank & BAI Europa \\
4 & Barclays & Banco BIC \\
5 & Moza Banco & BII \\
6 & Banco Único & Banco de Investimento Global \\
7 & BNI & Banco Português de Gestão \\
8 & BTM & BEST \\
9 & Banco Socremo de Moçambiquest \\
10 & & CGD \\
11 & & CBI \\
12 & & Efisa \\
13 & & Finantia \\
14 & & Montepio Investimento \\
15 & & Satander Totta \\
\hline
\end{tabular}

Notes: Definition of banks: BIM-Banco de Investimentos de Moçambique, BCI-Banco Comercial e de Investimentos, BNI-Banco Nacional de Investimentos, BTM-Banco Terra de Moçambique, BCP-Banco Comercial Português, BII-Banco de Investimento Imobiliário, BEST-Banco Electrónico de Serviço Total, CGD_Caixa Geral de Depósitos, CBI—Caixa Banco de Investimento. Source: The Author

Markets. Banks in their respective market have different opportunities offering way to this research. The investigation includes 120 observations, 45 corresponding to Mozambique and 75 corresponding to Portugal. Banks were selected based on the intentional non-probability sampling suggested by Marconi and Lakatos (2003), and correspond to all banks whose FS's are available for the periods chosen for the research (2012-2017).

The information was taken from non-consolidated FS's. The consolidated FS's allow us to assess the true financial position, economic performance and cash flows generated by the group (Gomes \& Pires, 2011). This finding is obvious given that when preparing the consolidated financial statements an entity aggregates the financial statements of the parent company and its subsidiaries line by line. However, this study intended to analyze banks in their own financial market context, isolating effects from subsidiaries (Some Portuguese banks have subsidiaries in Mozambique) so we chose the individual statements.

For Mozambique, the collection of account reports was made on the websites of each bank that have availability of account reports. For Portugal, information on the accounts reports was accessed through the Banco de Portugal website. For information taken directly from bank accounts, the values corresponding to the variables under study were extracted at their original value.

\subsection{Study Variables}

The study was based on the modified Jones (1991) model suggested by Dechow, 
Sloan and Sweeney (1995), which was designed for the industrial sector. According to Ugbede, Lizam and Kaseri (2013), the modified Jones model can be adjusted for the banking sector, replacing the sales variable with gross income and receivables with net loans, keeping the remaining variables constant. According to these authors, Gross Income can be calculated by adding interest, commission and service income, currency exchange income, equity instrument income and other income and Net Loans can be calculated by the difference between total loans and doubtful loans. Thus, the variables that were withdrawn in FS from the sample banks are: Earnings Before Tax (EBT), Operating Cash Flow (OCF), Total Assets (TA), Gross Income (GI), Net Loans (NL) and Fixed Assets Tangible (FAT).

\subsection{Analysis Models}

According to Martinez (2008), DAC's are proxy for accounting earnings, and can be calculated through the difference between Total Accruals (TAC) and NDAC. The authors as Martinez, 2008; Gabriel and Corrar, (2010) state that the accruals can be calculated through the difference between Profit before tax and Operating cash flow, as shown below:

$$
\mathrm{TAC}_{j t}=\mathrm{PBT}_{j t}-\mathrm{OCF}_{j t}
$$

TAC $_{j t}$ - Total accruals of bank $j$ in year $t$;

$\mathrm{PBT}_{j t}$-Profit before tax of bank $j$ in year $t$,

$\mathrm{OCF}_{j t}$-Operating cash flow of bank $j$ in year $t$.

The objective is to compute the banks' earnings in their economic sense, which represents the effective growth of the wealth of the economic unit regardless of the financial movement.

The initial phase of the present work is to estimate the DAC, and when it is proved that their absolute value is significantly different from zero, this situation indicates the existence of poor quality of income. Thus, the model for estimating the DAC, which corresponds to the model estimation errors $(\varepsilon)$ is as follows:

$$
\frac{\mathrm{TAC}_{j t}}{\mathrm{TA}_{j t-1}}=\alpha_{0}\left(\frac{1}{\mathrm{TA}_{j t-1}}\right)+\alpha_{1 j}\left(\frac{\Delta \mathrm{GI}_{j t}}{\mathrm{TA}_{j t-1}}-\frac{\Delta \mathrm{NL}_{j t}}{\mathrm{TA}_{j t-1}}\right)+\alpha_{2 j}\left(\frac{\mathrm{FAT}_{j t}}{\mathrm{AT}_{j t-1}}\right)+\varepsilon_{j t}
$$

$\mathrm{TAC}_{j t}$ - Total Accruals of bank $j$ in year $t$;

$\mathrm{TA}_{j t-1}$ - Total Assets of bank $j$ in year $t-1$;

$\Delta \mathrm{GI}_{j t}-$ Variation in gross income between the period $t$ and $t-1$;

$\Delta \mathrm{NL}_{j t}-$ Variation in net loans of bank $j$ between the period $t$ and $t-1$;

$\mathrm{FAT}_{j t}$-Fixed Tangible Assets of bank $j$ in period $t$,

$\varepsilon_{j t}$ - Model estimation errors.

The estimated DAC value for each bank and year can be either positive or negative or zero. Martinez (2008) states that the closer to zero, the better the quality of income reported by banks. Thus, when the value of DAC is positive or negative, this means that earnings manipulation was found. The following will apply the Student $t$-test to verify that the mean absolute value of the DAC is 
nonzero.

To test the first research hypothesis, if there is discretionary behavior in both Mozambican and Portuguese banks, the linear regression model was used to obtain the DAC. Then Student's $t$-test was used to verify if the mean DAC was statistically different from zero. To validate the second investigation hypothesis, the DAC of the two groups were compared to verify where there is greater discretion in the earnings of the sample banks by applying the Student's $t$ test for this purpose. To test the third research hypothesis, the coefficients between available-for-sale financial assets and total banks' assets were compared to see where financial assets are likely to be used for manipulation.

\section{Results and Discussions}

This chapter progressively presents results in the following sequence: a) Results of the DAC estimation model; b) Results of the comparison of the DAC averages for the two samples corresponding to the two different markets and c) Results of the comparison of the volumes of financial instruments used in the two markets.

\section{Quality Earnings Analysis}

To verify the quality of the earnings reported by the banks, the DAC's for each bank were estimated for the sample years. The mean estimation coefficients of the model are shown in Table 3.

To test the quality of reported earnings, it is necessary to verify that the absolute values of the DAC are significantly different from zero. For this purpose, the Student's $t$-test was used with the following hypotheses: $\mathrm{H}_{0}: \mu=0$ vs. $\mathrm{H}_{1}: \mu \neq 0$. The test result is shown in Table 4.

The test result allows rejecting $\mathrm{H}_{0}$ with $P$ value $=0.001$, and it can be concluded that the evidence suggests that the mean absolute value of the DAC is non-zero. Thus, the existence of discretionary behaviour $\left(\mathrm{H}_{1}\right)$ is confirmed, denoting the use of accounting practices by banks that influence the earnings, thus reducing their quality. This result is consistent with Elias and Alves (2015) who found discretionary behaviour in Portuguese and Nigerian banks. This finding is also consistent with other studies on earnings management as pointed out (Fernandes, 2007 and Goulart, 2007) that by choosing alternative solutions compatible with accounting principles, managers try to hide or improve company performance, but without violating generally accepted accounting principles.

The comparison of the DAC's for independent samples was then established, and they consisted separately of Portuguese and Mozambican banks. The results obtained allow us to conclude that there are statistically significant differences between the two groups and the homogeneous variances, as is shown in Table 5. Portuguese banks have higher DAC's than Mozambicans, since unilateral left testing allows us to reject $\mathrm{H}_{0}$ : Mozambican banks $\geq$ Portuguese banks. It can be said that the greatest discretion is attributed to Portugal. Table 5 gives the details: 
The results allow us to confirm $\mathrm{H}_{2}$, and it leads us to assume that the concentration of Financial Instruments increases chances for managers to make better choices consistent with the manipulation of results. The next analysis discusses this point.

Based on the previous finding, the coefficients between available-for-sale financial assets and total assets were compared to verify the level of use of financial instruments among asymmetric banks. The results found are presented in Table 6:

Table 3. Average estimation coefficients of the model [2].

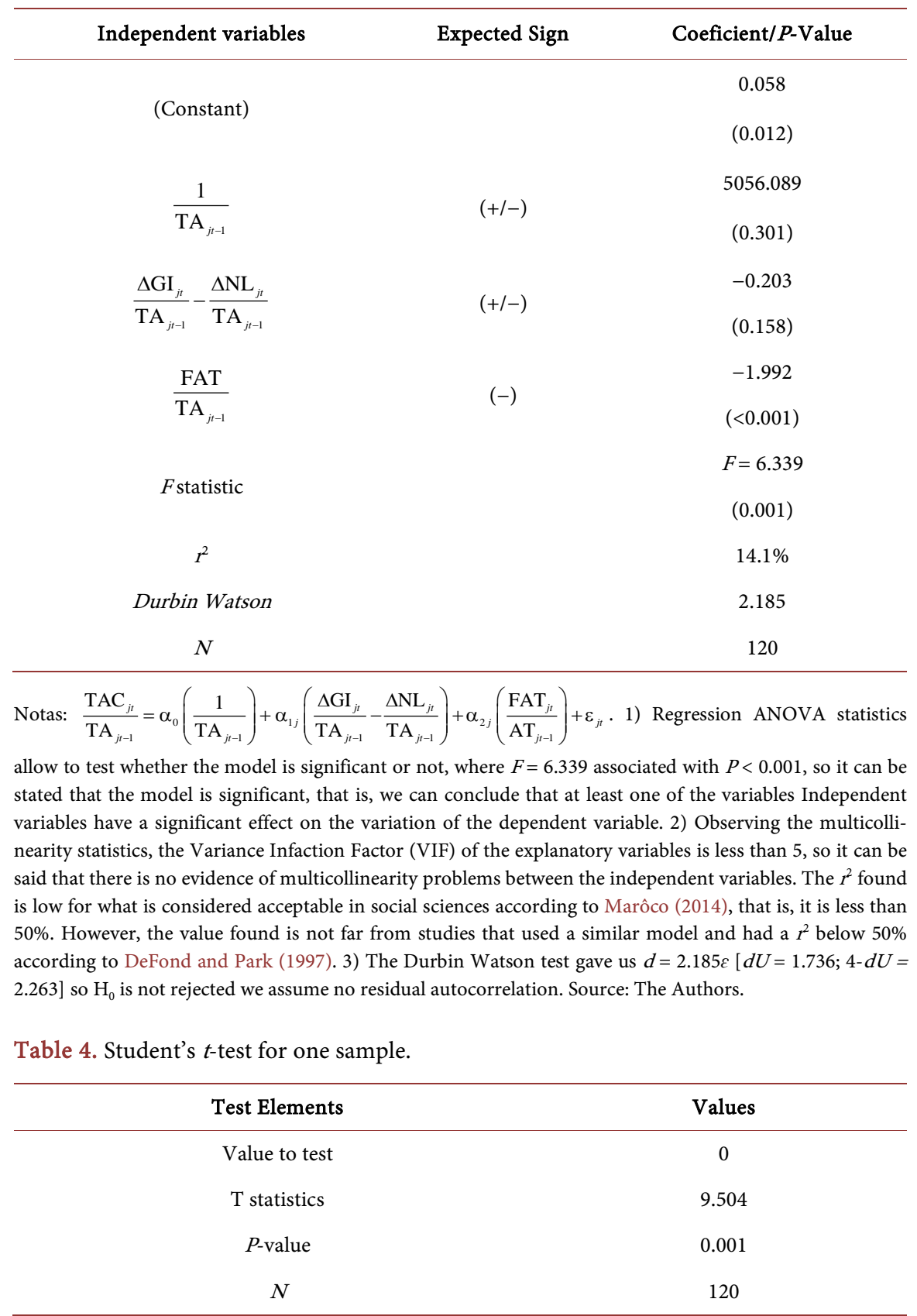

Source: The Authors. 
Table 5. Comparison of the average DAC of the samples.

\begin{tabular}{ccc}
\hline Countries & Test Elements & Values \\
\hline \multirow{2}{*}{ Mozambique } & Mean & 0.08 \\
& Standard deviation & 0.08 \\
& $N$ & 45 \\
Portugal & Mean & 0.13 \\
& Standard deviation & 0.13 \\
Levene test & $N$ & 75 \\
Two-tailed $t$-test & $F=3.426$ & $P$ Value: 0.067 \\
Unilateral $t$-test, Left & $t=(2.077)$ & $P$ Value: 0.040 \\
\hline
\end{tabular}

Source: The authors.

Table 6. Comparison of the level of use of financial instruments.

\begin{tabular}{cccc}
\hline & & \multicolumn{2}{c}{ Values } \\
\hline \multirow{2}{*}{ Countries } & Test Elements & FIAS/TA & FIHT/TA \\
\hline \multirow{2}{*}{ Mozambique } & Mean & 0.06 & 0.01 \\
& Standard deviation & 0.08 & 0.02 \\
Portugal & $N$ & 45 & 16 \\
& Mean & 0.11 & 0.006 \\
Standard deviation & 0.16 & 0.012 \\
FIAS/TA & $N$ & 75 & 59 \\
FIHT/TA & Two-tailed $t$-test & $t=-1.93$ & $P$ value: 0.06 \\
& Two-tailed $t$-test & $t=1.052$ & $P$ value: 0.30 \\
\hline
\end{tabular}

Source: The authors.

Table 6 shows that the average coefficients between FIAS and total assets for banks in Mozambique are lower than for banks in Portugal. Nevertheless, the difference is not significant according to the $t$-test. In this analysis, it was also noted that the constitution of FIAS for the Mozambican context is mostly composed of Treasury Bills. The latter are characterized by their low volatility.

Considering the results of $t$ test, $\mathrm{H}_{3}$ is therefore not confirmed. It is assumed that other factors may interfere to facilitate or encourage earnings manipulation practices. Ugbede et al. (2013) applied in their study the same modified Jones model to investigate discretionary behavior in banks in Malaysia and Nigeria. They found manipulative behavior in banks, and found significant differences between groups. In the end, they concluded that the structure and bad governance practices of Nigerian banks allow for greater frequency and broader scope of earnings manipulation, while good corporate governance, principles, structures and practices associated with Malaysian banks are key factors that prevent 
and limit the extent of degree of earning manipulation.

\section{Conclusion}

The present paper was developed with the objective of analyzing the differences in the discretionary levels of financial institutions in the context of emerging and dynamic markets. The banks that constituted the sample for the study belong to Mozambique and Portugal. The main evidence collection instrument used was to obtain the reports and accounts of the banks analyzed from 2013 to 2017.

DACs, which are proxy for quality of earnings, were tested to see if there is discretionary behavior in the reported earnings and compared to see where the highest level of discretion in the results of the sample banks occurs. The study results indicate that there is evidence of discretionary behaviour in the reported earnings and are high to the dynamic markets context. As a consequence of the previous finding, the use of financial instruments that can be measured at fair value was analysed. It was found that Mozambican banks use few instruments; however the difference is meaningless. A gross part of FIAS used in Mozambican's banks is treasure obligations which in part may explain that, although, they do not have flexible markets, they have no alternative to relatively higher manipulation than Portuguese banks.

The present study examines the issue of earnings manipulation within a narrow framework of the implementation of the FV to measure financial instruments; however, other factors such as 1) Shareholding and organizational structure of companies; 2) Other accounting standards and 3) Other assets other than Financial Instruments may interfere and explain the earning manipulation. Future studies may widen the research to analyze the different aspects that involve the earning manipulation.

This study also joins others that seek to improve methods of estimating discretion in Financial Institutions. However, the study is limited to the use of a single estimation procedure. It is suggested that future studies involve other procedures in order to add robustness to the results. It should be noted that the financial sector is by far the most sensitive in the economy and its deregulation can cause contagious damage to the world's economy.

\section{Conflicts of Interest}

The authors declare no conflicts of interest regarding the publication of this paper.

\section{References}

Bolsa de Valores de Moçambique (BVM). http://www.bvm.co.mz/index.php/pt/publicacoes/estatisticas

Buchweitz, M., Pereira, T., Da Cruz, A., \& Barbosa, M. (2019). Além de Watts e Zimmerman: A Precursão da Teoria Positiva da Contabilidade nos Estudos de Dumarchey e a Influência dos Autores na Literatura Contábil Permanente no Brasil. Revista do instituto de ciências econômicas, administrativas e contábeis, 23, 9-18. 
https://doi.org/10.17648/sinergia-2236-7608-v23n1-8136

Butler, C. (2009). Accounting for Financial Instruments. Chichester: Wiley.

CMVM (2018). Relatório sobre os Mercados de Valores Mobiliários. http://www.cmvm.pt/pt/EstatisticasEstudosEPublicacoes/Publicacoes/relatorio_valores _mobiliarios/Documents/R_VM_2018.pdf

Dechow, P., Sloan, R., \& Sweeney, A. (1995). Detecting Earnings Management. The Accounting Review, 70, 193-225.

DeFond, M., \& Park, C. (1997). Smoothing Income in Anticipation of Future Earnings. Journal of Accounting and Economics, 23, 115-139. https://doi.org/10.1016/S0165-4101(97)00004-9

Elias, C., \& Alves, J. (2015). Transição Da Contabilidade Baseada No Custo Histórico Para O Justo Valor: Suas Implicações Na Transparência Dos Resultados Reportados Por Instituições Bancárias. Gestin, 12, 51-64.

Fernandes, P. (2007). O Impacto da Entrada em Vigor das IFRS na Gestão de Resultados: A Experiência Ibérica. Tese de Mestrado em Ciências Empresariais-Finanças. Porto: Universidade do Porto.

Gabriel, F., \& Corrar, L. (2010). Gerenciamento de Resultados e de Capital no Sistema Bancário Brasileiro-Uma Investigação Empírica nas Aplicações em Títulos e Valores Mobiliários. Revista de Contabilidade do Mestrado em Ciências Contábeis da UERJ, 15, 49-62.

Gomes, J., \& Pires, J. (2011). Sistema de Normalização Contabilística (4a ed.). Porto: VidaEconómica.

Goulart, A. (2007). Gerenciamento de Resultados Contábeis em Instituições Financeiras no Brasil. Tese de Pós-Graduação em Contabilidade. São Paulo: Universidade de São Paulo.

Healy, P., \& Wahlen, J. (1999). A Review of the Earnings Management Literature and Its Implications for Standard Setting. American Accounting Association, 13, 365-383. https://doi.org/10.2308/acch.1999.13.4.365

Jones, J. (1991). Earnings Management during Import Relief Investigation. Journal of Accounting Research, 29, 193-228. https://doi.org/10.2307/2491047

Khan, U. (2010). Does Fair Value Accounting Contribute to Systemic Risk in the Banking Industry? https://doi.org/10.2139/ssrn.1911895 http://ssrn.com/abstract $=1327596$

Marconi, M., \& Lakatos, E. (2003). Fundamentos de Metodologia Científica (5th ed.). São Paulo: Atlas.

Marôco, J. (2014). Análise estatística com o SPSS Statistics (6ª ed.). Perô Pinheiro: Report Number.

Martinez, A. (2008). Detectando Earnings Management no Brazil: Estimando os Acréscimos discricionários. Revista de Contabilidade e Finanças, 19, 7-17. https://doi.org/10.1590/S1519-70772008000100002

Moreira, J. (2013). Pode um investidor medianamente diligente detectar a manipulação dos resultados das empresas? Estudo do caso Worldcom. Porto: Edições Húmus.

Silva, A. (2008). Escolha de Práticas Contábeis no Brasil: Uma Análise sob a Ótica da Hipótese dos Convenants Contratuais. Tese de Doutorado em Ciências Contábeis, São Paulo: Universidade de São Paulo.

Silva, M., Silva, J., Souza, F., Borges, E., \& Araújo, A. (2015). Uma Abordagem da Teoria Positiva da Contabilidade Aplicada no Sector Público. Revista de Administração e Contabilidade, 7, 2-19. 
Ugbede, O., Lizam, M., \& Kaseri, A. (2013). Corporate Governance and Earnings Management: Empirical Evidence from Malaysian and Nigerian Banks. Asian Journal of Management Sciences and Education, 2, 1-21.

Watts, R., \& Zimmerman, J. (1990). Positive Accounting Theory: A Ten Years Perspective. The Accounting Review, 65, 131-156. 